\title{
PHYTOCONSTITUENTS, PHARMACOLOGICAL ACTIVITY, AND MEDICINAL USE OF LEPIDIUM SATIVUM LINN.: A REVIEW
}

\author{
CHETNA BAREGAMA ${ }^{1,2 *}$, ANJU GOYAL ${ }^{1}$ \\ ${ }^{1}$ Department of Pharmacy, Bhupal Nobles' Institute of Pharmaceutical Sciences, Udaipur, Rajasthan, India. ${ }^{2}$ Department of Medicinal and \\ Pharmaceutical Chemistry, B. R. Nahata College of Pharmacy, Mandsaur University, Mandsaur, Madhya Pradesh, India. \\ Email: chetnabaregama@gmail.com \\ Received: 04 January 2019, Revised and Accepted: 13 March 2019
}

ABSTRACT

Herbal medicines are in nice demand within the developed additionally as developing countries for primary aid due to their wide biological and medicative activities, higher safety margins, and lesser prices. Lepidium sativum Linn. (Brassicaceae) is annual herb regionally referred to as halon in India, however, usually referred to as garden cress. L. sativum is a fast growing edible plant. Seeds, roots, and leaves of garden cress have economic importance; however, the crop is especially cultivated for seeds. It is a therapeutic vital herb in India. L. sativum has various pharmacological actions such as antibacterial activity, antifungal activity, antioxidant activity, cytotoxic activity, diuretic activity, hepatoprotective activity, hypoglycemic activity, antiosteoporotic activity, antiasthmatic activity, anti-carcinogenic effect, cardiotonic activity, smooth and skeletal muscles contraction activity, fracture healing property, chemoprotective effects, and hemagglutinating activity. It is used for menstrual cycle regulation, gastrointestinal problems such as diarrhea and constipation and to increase milk production. It is also reported to exhibit antirheumatic activity. It is also used as an immunity booster and brain intellect enhancer agent as traditional medicine. Thus this review reveal that L. sativum is a source of medicinally active compounds and have a variety of pharmacological effects. These studies will be helpful to create focus toward L. sativum and may be useful in developing new formulations with more therapeutic and to provide a direction for advance research.

Keywords: Lepidium sativum, Pharmacological activity, Herbal medicine, Phytoconstituents, Garden cress.

(C) 2019 The Authors. Published by Innovare Academic Sciences Pvt Ltd. This is an open access article under the CC BY license (http://creativecommons. org/licenses/by/4. 0/) DOI: http://dx.doi.org/10.22159/ajpcr.2019.v12i4.31292

\section{INTRODUCTION}

Herbal medicines are in nice demand within the developed additionally as developing countries for primary aid due to their wide biological and medicinal activities, higher safety margins, and lesser prices. Once decades of significant obsession with the trendy medical system, individuals have started gazing the traditional healing systems such as Ayurveda, Siddha, and Unani to treat the assorted styles of ailments. This is due to the adverse effects related to synthetic drugs. In recent times, target plant analysis has redoubled everywhere the globe, and an outsized body of proof has collected to indicate large potential of healthful plants utilized in varied ancient systems. Herbal traditional medicines have gained considerable momentum worldwide during the past decade and play a paramount role in health-care programs especially in developing countries. Ancient Indian literature incorporates a remarkably broad definition of healthful plants and considers all plant components to be potential sources of medicinal substances [1].

However, a key obstacle that has hindered the acceptance of the herbal medicines within the developed countries is that the lack of documentation and non-compliance of Good Manufacturing Practice guidelines due to poor standardization level. It is important that a system of standardization should be established for each plant medication within the market, as a result of the scope for variation in several batches of drugs is vast. Due to natural heterogeneousness, material might vary in its phytochemical contents and thus in its therapeutic result in keeping with totally different places of gathering, with totally different times during a year for gathering, with gathering at an equivalent time and places however in totally different years and with different environmental factors encompassing the cultivation of a specific healthful plant. Adding to the current variability, its the actual fact that in seasoning drugs many plants are also used along within the same preparation. These factors substantiate the basic want of standardized internal control tests for seasoning preparations to make sure the quality of the product. There is an internationally increasing demand for documentation of analysis work administrated on ancient medicines [2].

Lepidium sativum Linn. (Brassicaceae) is annual herb regionally referred to as halon in India, however, usually referred to as garden cress. L. sativum is a fast growing edible plant. Seeds, roots, and leaves of garden cress have economic importance; however, the crop is especially cultivated for seeds. It is a therapeutic vital herb in India [3]. It is an erect, glabrous, yearly, herbaceous plant growing up to $15-45 \mathrm{~cm}$ in height. It has little white flowers in long racemes. The pods of L. sativum are obovate, rotundate, elliptic, irregular at apex emarginated, and winged. It can be developed at all the elevations, throughout the year; however, the most effective herb is obtained within the winter season. The leaves of the plant utilized in salads, cooked with other vegetables and used to decorate food. Leaves have diuretic and stimulant action $[4,5]$. Halon seeds are brownish red in color and oval in shape [6].

\section{PHARMACOLOGICAL ACTIVITIES OF L. SATIVUM}

L. sativum has various pharmacological actions such as antibacterial activity, antifungal activity, antioxidant activity, cytotoxic activity, diuretic activity, hepatoprotective activity, hypoglycemic activity, antiosteoporotic activity, antiasthmatic activity, anti-carcinogenic effect, cardiotonic activity, smooth and skeletal muscles contraction activity, fracture healing property, chemoprotective effects, and hemagglutinating activity. It is used for menstrual cycle regulation, gastrointestinal problems such as diarrhea and constipation and to increase milk production. Other uses GC seed includes iron deficiency treatment, dermatological treatment, hair loss treatment, and immunity booster and also has an aphrodisiac effect. It is also reported to exhibit antirheumatic activity. It is also useful in hiccup, dysentery, diarrhea, and skin disease caused by impurities of blood. It also progresses brain power and brighten up the intellect [7]. 


\section{PLANT PROFILE}

\section{Morphology of the plant}

L. sativum L. is an edible herb and it is member of the Cruciferae (Brassicaceae) family. L. sativum is an yearly, glabrous, and vertical herb cultivated as a culinary vegetable all over Asia and Europe. It is commonly cultivated throughout the temperate regions of India and Pakistan [8].

It has small white flowers in long racemes and the pods are broadly or obovate, rotund, elliptic, emarginated, notched at apex, and winged. Garden cress can be sown and harvested several times throughout the year, the January, February, and November are the most suitable months of the year to sow in a Mediterranean climate [9]. It is a vertical, branched, and glabrous plant. It is near about $60 \mathrm{~cm}$ in height. It has entire or pinnately dissected leaves, variously lobed often with linear segments; up to $6-5 \mathrm{~cm}$ long and lobes are $0.7-1.2-0.3-0.6 \mathrm{~cm}$ size, upper leaves usually entire, and $2-3 \mathrm{~cm}$ long, oblanceolate, sessile. Racemes are 7-15 cm long axillary and terminal; white or pale pink flowers, $3-5 \mathrm{~mm}$ long pedicels. It has obovate or broadly elliptical, roundate pods which are emarginated slightly but thickly winged above [10].

\section{Taxonomical classification}

Kingdom: Plantae;

Subkingdom: Tracheobionta;

Super division: Spermatophyta;

Division: Magnoliophyta;

Class: Magnoliopsida;

Subclass: Dilleniidae;

Order: Capparales;

Family: Brassicaceae;

Genus: Lepidium L.

Species: Lepidium sativum L. [11]

Seeds are small, oval-shaped pointed, and triangular at one end, smooth about 2-3 $\mathrm{mm}$ long and 1-1.5 mm wide, reddish brown, an arrow present on both surfaces, extending up to two-thirds downwards, a slight wing-like extension present on both the edges of seed when soaked in water seed coat swells and gets covered with a transparent, colorless mucilage [8]. Seeds show micropyle and grove in between which can be easily seen in its lateral view and dorsal view. In both transverse section and longitudinal section, seeds show testa, radical, and cotyledon. Its embryo shows cotyledon, radical, and on superior part lobes of cotyledon. These structures are much clearly seen in enlarge embryo. Transverse section of radical shows a thin layer of epidermis on the outer side than it shows cortex of parenchymatous cells. The additional layer is of endodermis which enclosed the vascular bundle inside [12].

\section{PHYTOCONSTITUENTS}

The complete plant contains Glucotropaeolin, 4-methoxyglucobrassicin, esters of caffeic, $\beta$-sitosterol, benzylcyanide, calmodulin, sinapoyglucose, p-coumaric, ferulic, quinic acids, protein, mineral, vitamin, 5-4'-dihydroxy7,8,3',5-tetramethoxyflavone, 5-3'-dihydroxy-7,8,4' tetramethoxyflavone, and 5-3'-dihydroxy-6,7,4'-tetramethoxyflavone [13]. Preliminary phytochemical screening showed the presence of carbohydrates, phenolic compounds, flavonoids, alkaloids, proteins, saponins and lipids in the drug extract [14]. The chemical study has shown that seeds and leaves have Vitamin A, thiamine, riboflavin, niacin and ascorbic acid, and secondary metabolites as sinapic acid and its choline ester (sinapine) and flavonoids. Leaves also contain sinapoylglucose, esters of caffeic, pcoumaric, ferulic, quinic acids, and the esters of flavonoids $[15,16]$.

\section{LEAF}

Leaf contains protein, fat, carbohydrates, mineral, phosphorus (P), calcium (Ca), trace elements- iron, nickel, cobal, iodine, Vitamin A, thiamine, riboflavin, niacin, and ascorbic acid [17]. $\mathrm{N}$-Butanol fraction of aqueous-methanolic extract of leaves afforded three flavonol glycosides, quercetin-3-0- $\beta$-glucosyl $(1 \rightarrow 2)$ glucopyranoside- 7-0- glucopyranoside, kaempferol-3-0- $\beta$ - glucosyl (1 $\rightarrow 2$ )- glucopyranoside - 7 - 0 - $\beta$ - glucopyransoide, and isorhamnetin - 3 - 0 - sophoroside - 7 - O - $\beta$ - D - glucopyransoide [18].

\section{SEEDS}

Chemical constituents in seeds of the plant mainly contains alkaloids such as lepidine, glucotropaeolin (GT), N, N'-dibenzyl urea, N, N'-dibenzylthiourea, sinapic acid and its choline ester (sinapine); the bioactive flavonoids such as 5-4-dihydroxy-7, 8, 3, 5 tetramethoxyflavone, and 5-3-dihydroxy-6, 7, 4' trimethoxyflavone have been isolated [19].

Seed contains $20-25 \%$ yellowish semi drying oil and the major fatty acid in it is alpha-linolenic acid (32-34.0\%) [20]. It has a balanced amount of polyunsaturated fatty acids $(46.8 \%)$ and monounsaturated fatty acids (37.6\%) and also contains ordinary antioxidants, namely tocopherols and carotenoids which defend the oil from rancidity [21]. It also contains palmetic, stearic, oleic, linolenic, arachidic, behenic, lignoceric acids, benzyl isothiocyanate, benzyl cyanide, sterol, and sitosterol [22,23]. The seeds of L. sativum showed significant antibacterial activity against a number of pathogenic bacteria responsible for severe infections; this might be due to the presence of benzyl isothiocyanate [24]. Infections caused by these bacteria, especially those with multidrug resistance, are among the most difficult ones to treat with conventional antibiotics. Glucosinolates are the major secondary metabolites of L. sativum, and the extracts have chemopreventive effects in inhibiting carcinogenesis [25]. The seeds contain edible oil which is rich in alpha-linolenic acid with an ideal ratio of omega-3 and 6-fatty acids $[26,27]$ as well as imidazole alkaloids [28]. Other chemical constituents like lepidine, lepidine B, C, D, E and F, semilepidinoside A and B are also present in seeds [29]. The scavenging activity might be due to the presence of total polyphenolic compounds. These polyphenolic compounds include flavonoids, anthraquinones, anthocyanins, xanthones, and tannins [30]. Seeds have protein about $25 \%$, lipids about $14-24 \%, 33-54 \%$ of carbohydrates, and $8 \%$ of crude fiber [31,32]. The carbohydrates consist of $90.0 \%$ non-starch polysaccharides and $10 \%$ of starch. The seed bran has high nutritional fiber content and also it has high water holding ability. GC bran can be used as a rich source of dietary fiber [33]. It also contains mucilage, which on reaction with water gives arabinose, galactose, glucose, mannose, xylose, and various uronic acids are the most commonly observed components [34].

\section{TRADITIONAL USES}

The aerial parts are used in the cure of asthma, cough, and bleeding piles. The seeds are chewed to cure sore throat, cough, asthma, and headache, and in huge quantities to induce abortion. They are also applied outwardly as an insect repulsive. Leaves have stimulant and diuretic action, and important in scorbutic diseases and liver illness. The roots are used to treat syphilis. In Europe, the herb is used to treat cough and constipation, as a diuretic and to recover the immune system. The fresh fruit is useful for injuries, skins, and eye diseases. Seeds hot, leaves hot, and dry used as diuretic, aperients, bechic, aphrodisiac, good in inflammation and affections of spleen, in chest complaints, bronchitis, rheumatism, and muscular pains, improve brain power and brightens the intellect. The plant is also used in cases of asthma, cough with expectoration, and bleeding piles. Root is used in secondary syphilis and tenesmus. The seeds also have galactogogue activity, administered after boil with milk to cause abortion. A drug is also an act as gentle and warm aperients. Leaves are slightly stimulant and diuretic, helpful in scorbutic diseases $[35,36,37]$.

\section{REPORTED ACTIVITY}

L. sativum has various pharmacological actions such as antibacterial activity, antifungal activity, antioxidant activity, cytotoxic activity, diuretic activity, hepatoprotective activity, hypoglycemic activity, antiosteoporotic activity, antiasthmatic activity, anti-carcinogenic effect, cardiotonic activity, smooth and skeletal muscles contraction activity, fracture healing property, chemoprotective effects, and hemagglutinating 
activity. It is used for menstrual cycle regulation, gastrointestinal problems such as diarrhea and constipation and to increase milk production. It is also reported to exhibit antirheumatic activity [38].

\section{PHARMACOLOGICAL REVIEW}

\section{Antibacterial activity}

L. sativum extracts are effective against various bacteria used in this study. According to the results of this study show that the methanol extract revealed prominent antibacterial activity on Staphylococcus aureus $(22 \mathrm{~mm})$, Bacillus cereus $(16 \mathrm{~mm})$, Escherichia coli $(14 \mathrm{~mm})$, Pseudomonas aeruginosa (14 mm), Micrococcus luteus (16 mm), and Salmonella typhi $(13 \mathrm{~mm})$, respectively, in terms of zone of inhibition, while the ethyl acetate extract exhibited moderate effect and the other two extracts showed weak inhibition on the growth of the organisms. The zone of inhibition being prominent in methanol extract; therefore, the minimum inhibitory concentration (MIC) and minimum bactericidal concentration (MBC) studies of extract were carried out. The results showed that $S$. aureus had the highest MIC $(1.56 \mathrm{mg} / \mathrm{ml})$ and MBC $(6.52 \mathrm{mg} / \mathrm{ml})$, while the lowest MIC of $25 \mathrm{mg} / \mathrm{ml}$ was shown by $S$. typhi [39].

\section{Antifungal activity}

The antifungal potential of the methanolic extract of L. sativum seeds against the tested fungi at different concentrations. It is revealed that the methanolic extract at a concentration of $30 \mathrm{mg} / \mathrm{ml}$ completely inhibited the growth of Aspergillus flavus. Toward the end of the incubation period, Rhizopus sp. showed slow and weak growth on $30 \mathrm{mg} / \mathrm{ml}$ and $60 \mathrm{mg} / \mathrm{ml}$ slant and was completely inhibited at $90 \mathrm{mg} / \mathrm{ml}$. At a concentration of $90 \mathrm{mg} / \mathrm{ml}$, the fungi Aspergillus fumigatus, Candida albicans, Fusarium sp., Microsporum sp., Penicillium sp., and Penicillium marneffi were completely inhibited [40].

\section{Antioxidant activity}

Extraction of powdered parts (shoot, seed, stem, and leaves) of L. sativum was carried out with ethanol using Soxhlet extraction equipment. Then under reduced pressure and controlled temperature, the ethanolic extracts were dried. The crude dried powdered materials which are ethanol free, were used for experiments. The extracts were individually dissolved in dimethyl sulfoxide and used for particular assays. L. sativum ethanolic extract (LSEE) was also analyzed for free radical scavenging and antioxidant activities using 2,2-diphenyl-1picrylhydrazyl-hydrate assay, glutathione S-transferase activity and quantify in reduced glutathione content. The results show that the extracts contain high antioxidant activities and thus form a potential source of natural antioxidant compounds [41].

\section{Cytotoxic activity}

L. sativum seeds and leaves which contain flavonoids were investigated for their cytotoxic activities toward HEp2 cells. The results obtained in this study showed that ethyl acetate extract ( $\mathrm{O}$-glycosides) of $L$. sativum seeds had the best cytotoxic effect toward HEp2 cells followed by butanol seed extract. This study reports the first study on flavonoids of L. sativum leaves, this conclude that all extracts have a good cytotoxic activity [42].

\section{Diuretic activity}

A dose-dependent increased in urine excretion showed by L. sativum. With the aqueous extract, the maximum increase in urinary excretion was produced at $100 \mathrm{mg} / \mathrm{kg}$ with a value of $49.89 \%$ compared while the methanol extract $(100 \mathrm{mg} / \mathrm{kg})$ showed an increase of $41.05 \%$ grouping urine volume. The specific conductivity was increased in a dose-dependent manner in all the extract-treated groups which are an indirect measure of the ionic content of the urine. Thus, the diuretic effect of aqueous and methanol extract is indicated by an increase in both water excretion and excretion of sodium and potassium. The active principles responsible for the diuretic effects of the extracts of this plant have not yet been confirmed, but the preliminary phytochemical study of the extracts revealed the presence of polar compounds such as flavonoids and steroids [43].
Hepatoprotective activity

LSEE is effective in the prevention of d-galactosamine/ lipopolysaccharides (D-GalN/LPS)-induced hepatic damage in rats. The pretreatment with LSEE considerably prevented the D-GalN/LPS induced upsurge in liver functional enzymes (aspartate transaminase, alanine aminotransferase, Gamma-glutamyltransferase, alkaline phosphatase (ALP), total bilirubin, lactate dehydrogenase, and total protein). Thus, significantly alleviate the reduction of lipid peroxidation and restored the antioxidant enzymes and total protein to normal levels. LSEE decreases hepatic injuries and structural damage through the decline of oxidative stress, inflammation, and apoptosis in the liver [44].

\section{Hypoglycemic activity}

This study intended at the investigation of antidiabetic efficacy of L. sativum seed total alkaloid (LSTA). The main ingredients of this alkaloid fraction are lepidine and semilepidine, a rare group of imidazole alkaloid. Hypoglycemic profile of LSTA (50, 150, and $250 \mathrm{mg} / \mathrm{kg}$, i.p.) was examined on alloxan-induced diabetic rats on 21 days continuous treatment. Biochemical parameters such as glucose, total cholesterol, triglycerides, low-density lipoprotein, high-density lipoprotein, urea, and creatinine were determined along with body wt. and relative organ weight. LTSA at $250 \mathrm{mg} / \mathrm{kg}$ showed $1.94 \%$ body wt. gain on the $21^{\text {st }}$ day relative to 6.14 and $8.94 \%$ of control and diabetic group. LSTA considerably $(\mathrm{p}<0.001)$ suppressed blood glucose, cholesterol, triglyceride, and urea level in diabetic rats at $250 \mathrm{mg} / \mathrm{kg}$ dose. According to the above results, LSTAat dose $250 \mathrm{mg} / \mathrm{kg}$ is showed potent hypoglycemic activity. The L. sativum alkaloid shows that hypoglycemic activity against alloxan-induced diabetes may be by reducing oxidative damage and modulating antioxidant enzymes. It is assumed that the mechanism by which LSTA brings about its hypoglycemic activity is potentiation of pancreatic secretion of insulin from the remaining $\beta$ cells [45].

\section{ANTIOSTEOPOROTIC EFFECT B}

L. sativum seeds have been used in conventional folk medicine to heal fractured bones. However, there is a lack of information on the impact of GC on bone metabolism especially in cases of glucocorticoids-induced osteoporosis (GIO). Therefore, the aim of the study was to contrast the biochemical bone markers and histological responses of GC alone ( $6 \mathrm{~g}$ of GC seeds in diet daily, $\mathrm{n}=8$ ), atomic layer deposition (ALD) (alendronate, $70 \mathrm{mg} / \mathrm{kg}$ s.c.; $\mathrm{n}=8$ ) alone, or GC and ALD joint in a rat model of GIO by injecting rats with methylprednisolone $3.5 \mathrm{mg} / \mathrm{kg}$ per day for 4 weeks. Serum Ca, albumin, P, bone-specific ALP (b-ALP), and tartrate-resistant acid phosphatase (TRAP) were measured 4 weeks after the beginning of GIO. GIO-group showed significantly augmented serum TRAP and decreased b-ALP. GIO-group is also showed significantly decreased serum $\mathrm{P}$ and unaffected Ca concentrations. Histological examination of GIO-group tibia bones indicated an osteoporotic change and an associated decrease in the percentage of the trabecular area or bone marrow area (PTB) in the proximal femoral epiphysis. Treatment with either GC and/or ALD ameliorated the above-mentioned changes with variable degrees, with a net result of improved serum $\mathrm{Ca}$, bone architecture, PTB, b-ALP and decreased TRAP in GC and GC+ALD groups compared to that of animals treated with alendronate alone. In conclusion, this study related findings present evidence supporting the probable benefits of L. sativum in reducing the burden of glucocorticoids on bone health [46].

\section{USE IN AIRWAYS DISORDERS}

L. sativum is widely used in folk medicine for the management of hyperactive airways disorders, such as asthma, bronchitis, and cough. The crude extract of L. sativum (Ls.Cr) inhibited carbachol (CCh, $1 \mu \mathrm{M}-)$ and $\mathrm{K}+(80 \mathrm{mM}-)$ provoke contractions in a pattern like to that of dicyclomine. Ls.Cr at a concentration of $0.03 \mathrm{mg} / \mathrm{mL}$ produced a rightward parallel shift of CCh curves, followed by a nonparallel shift at an upper concentration $(0.1 \mathrm{mg} / \mathrm{mL})$, suppressing highest response, and similar to that caused by dicyclomine. Pretreatment of tissues with $\mathrm{Ls}$.Cr (0.1-0.3 mg/mL) shifted Ca++ concentration-response curves (CRCs) to right, as formed by verapamil. Ls.Cr at low concentrations $(0.03-0.1 \mathrm{mg} /$ 
$\mathrm{mL}$ ) caused leftward shift of isoprenaline-induced inhibitory CRCs, like that produced by rolipram, a phosphodiesterase (PDE) inhibitor. According to the results, bronchodilatory effect of L. sativum is mediated through a mixture of three mechanism: $\mathrm{Ca}++$ antagonist, anticholinergic, and PDE inhibitory pathways. All these information form basis for utilization of L. sativum in the overactive airways disorders [47].

\section{ANTIASTHMATIC ACTIVITY}

The clinical efficacy of L. sativum has been reported in patients of bronchial asthma. For estimation of antiasthmatic activity, L. sativum seed powder was given at a dose of $1 \mathrm{~g} 3$ times a day orally to 30 patients of either sex in the range of 15-80 years with mild-to-moderate bronchial asthma lacking any parallel medication. The respiratory functions (forced volume vital capacity, forced expiratory volume 1, forced expiratory flow $25-75 \%$, and maximum voluntary ventilation) were determined using a spirometer before and after 4 weeks of treatment. Efficacy of the drug in improving clinical symptoms and severity of asthmatic attacks was checked by interviewing the patient and by physical and hematological evaluation at the end of the treatment. 4 weeks treatment with the drug showed statistically considerable enhancement in various parameters of pulmonary functions in asthmatic subjects. Furthermore, significant progress was observed in clinical symptoms and severity of asthmatic attacks. The adverse effect with L. sativum is not showed by a single patient [48].

\section{FRACTURE HEALING PROPERTY}

The effect of L. sativum used for fracture healing in Saudi folk medicine was studied on collagen deposition and tensile strength in experimental models. L. sativum significantly increased collagen deposition at fracture position. The tensile strength of the broken tibiae also increased in the L. sativum treated group [49]

\section{CARDIOTONIC AGENT}

Preliminary pharmacological studies on seeds of L. sativum have recommended the existence of cardioactive substance and are shown to have possible action through adrenergic mechanisms. Ethanolic extract of the seeds of L. sativum (10-20 mg/kg, i.v.) caused marked an increase in blood pressure (40-80 $\mathrm{mmHg}$ and 5-15 $\mathrm{min}$ ) of anesthetized cats and dogs. The hypertensive effect was linked with slight respiratory stimulation, but this effect was of transient duration (0.5-1 min). The extract was not found to potentiate or lower the pressor responses of adrenaline $(2 \mu \mathrm{g} / \mathrm{kg}$, i.v. $)$ and carotid occlusion (45 s). The extract $(10-20 \mathrm{mg} / \mathrm{kg}$, i.v.) caused marked improve in the rate and force of auricular and ventricular movements of open chest cat heart preparation in situ. The cardiostimulant effect was also observed on isolated rabbit auricles.

\section{SMOOTH AND SKELETAL MUSCLES CONTRACTION}

Ethanolic extract of the seeds of garden cress (1-5 mg/ml) shows no action on smooth muscles (rat ileum and rat uterus). The response to each $(0.5-2 \mu \mathrm{g} / \mathrm{ml})$ of these tissues was also not affected by the extract. The extract was also create to show contractile action on frog rectus abdominis muscle [50].

\section{CHEMOPROTECTIVE EFFECTS}

L. sativum constituents, GT and benzylisothiocyanate (BITC), a breakdown product of GT were checked for chemoprotective effects toward 2-amino-3-methyl-imidazo [4,5-f] quinoline (IQ)-induced genotoxic effects and colonic preneoplastic lesions in single cell gel electrophoresis assays and in aberrant crypt foci experimental procedure, respectively. Pretreatment of F344 rats with either fresh L. sativum juice $(0.8 \mathrm{ml})$, GT $(150 \mathrm{mg} / \mathrm{kg})$ or BITC $(70 \mathrm{mg} / \mathrm{kg})$ for 3 successive days caused a major $(\mathrm{p}<0.05)$ decrease in IQ $(90 \mathrm{mg} / \mathrm{kg}$ and $0.2 \mathrm{ml}$ corn oil/animal)-induced DNA damage in colon and liver cells in the sort of 75-92\%. Chemical investigation of GC juice showed that BITC does not account for the effects of the juice as its concentration in the juice was found to be 1000 -fold lower than the dose required to produce a chemoprotective effect. Parallel to the chemoprotection experiments, the modulation of the activities of cytochrome P4501A2, glutathione-S-transferase, and UDP glucuronosyltransferase by GC juice, GT, and BITC was examined. Whereas GT and BITC did not affect the activity of any of the enzymes significantly, GC juice caused a significant ( $p$ or $=4$ ) was reduced significantly $(\mathrm{p}<0.05)$ in the group that received IQ plus GC juice compared with the group that was treated with IQ only [51].

\section{HEMAGGLUTINATING ACTIVITY}

A lectin has been isolated from extracts of $L$. sativum by affinity chromatography on human immunoglobulin-Sepharose. The lectin reacts with human red blood cells without specificity for the A, B, and $O$ blood groups. Red blood cells of animal origin are also agglutinated by the lectin. The hemagglutinating activity is stopped by heating the lectin solution at $70^{\circ} \mathrm{C}$ or by dialysis against strong acid buffers [52]

\section{ANTI-CARCINOGENIC EFFECT}

Leaf aqueous extracts of garden cress were investigated for anticancer activity on human tongue squamous carcinoma (CAL-27). The results showed that the plant extract hinder the growth of CAL-27 cells in a dose-dependent manner $(70,100$, and $150 \mu \mathrm{g} / \mathrm{ml}$, respectively). The toxic effect of $L$. sativum extract causes notably ( $\mathrm{p}<0.05$ and $\mathrm{p}<0.01$ ) damage to DNA and raise the percentage of apoptotic nuclei to reach (30\% and $60 \%$ ) at concentrations of 100 and $150 \mu \mathrm{g} / \mathrm{ml}$, respectively. Results also showed that the $L$. sativum produce reactive oxygen species in the mitochondria of CAL-27 cells compared to untreated control. The aqueous extract of the leaves of garden cress holds large promise for the development of effective drugs for oral cancer treatment strategies [53].

\section{GASTROINTESTINAL TREATMENT}

L. sativum can be used as a laxative and purgative for patients suffering from constipation. L. sativum seeds can be blended and mixed with honey, which is used for treating diarrhea and dysentery. L. sativum can be blended and infused with hot water, which is used for treating colic, especially in children. Garden cress aqueous-methanolic extract of seeds at 30 and $100 \mathrm{mg} / \mathrm{kg}$ showed atropine-sensitive prokinetic and laxative activities in mice, which were sensitive partially to atropine. In isolated gut preparations of mouse and guinea-pig, L. sativum seeds (0.1-1 $\mathrm{mg} / \mathrm{mL})$ caused concentration-dependent stimulatory effects both in jejunum and ileum, which was blocked in the presence of atropine. In rabbit jejunum, the stimulant effect of $L$ sativum seeds remained unchanged in the presence of atropine, pyrilamine or SB203186, while in rabbit ileum; the stimulatory effect was partially blocked by atropine. The $L$. sativum seeds were more effective in gut preparations of a rabbit than in guinea-pig or mouse. This study showed the prokinetic and laxative effects of $L$. sativum in mice, which were somewhat mediated through a cholinergic pathway. The in vitro spasmodic effect of the plant extract mediated through the same mechanism with species and tissue-selectivity provides a basis for the medicinal use of the seeds of L. sativum in indigestion and constipation [54].

\section{IRON DEFICIENCY TREATMENT}

Iron deficiency is one of the major public health problems which affect especially adolescent girls. Hence, the present study was carried out to study the impact of garden cress seed incorporated atta besan ladoo (GABL) among anemic adolescent girls. A sample of 300 adolescent girls of age 13-18 years were selected. Hemoglobin was estimated through cyanmethemoglobin method. Data were analyzed using SPSS 16. 100 anemic girls (control $[\mathrm{n}=40]$ and experiment $[\mathrm{n}=60]$ ) were selected for experimental trial. Two GABL (140 g) were supplemented in the experimental group for a period of 2 months. Deworming was done before supplementation in experiment group only not in the control group. After 2 months of supplementation, the hemoglobin $(\mathrm{g} / \mathrm{dl})$ gradually increased in the experimental group from $10.17 \pm 0.88$ to $10.77 \pm 0.90$. No specific change was occur in the control group. 
L. sativum seeds are used for treating patients suffering from iron insufficiency anemia. Consumption of these seeds helps to improve the hemoglobin level over time [55].

\section{MENSTRUAL CYCLE REGULATION}

Our overall goals in these studies were first to determine the effect of LS seed consumption, both in the acute and chronic states, on the endocrinology of ovulation, second on the development of visceral organs and finally on the indices of spermatogenesis in the male rat model. We have demonstrated that a preovulatory surge-like gonadotropin-releasing hormone $(\mathrm{GnRH})$ secretion is inducible in vitro in the ovariectomized, estrogen-primed, and progesterone-treated rats. Our results indicated that LS supplementation tended to cause an earlier, attenuated preovulatory surge-like GnRH secretion. Temporally, LH secretion from the pituitary gland in all treatment groups decreased over time. Perifusate LH levels were high varying from 15 to $36 \mathrm{ng} / \mathrm{mL}$ pre-GnRH administration. We observed no stimulatory effect of $10 \mathrm{ng} / \mathrm{mL} \mathrm{GnRH}$ administration. Consequently, no surge-like LH secretion was observed. Future studies should investigate the use of a higher concentration of GnRH to stimulate the surge of LH. There was, however, a suppressive effect of progesterone in progesterone-treated rats on average LH secretion. Overall, follicle-stimulating hormone (FSH) decreased from time 0 to about 180 min before stabilizing. Average FSH levels were significantly higher in ovariectomized, estrogen-primed, progesterone-treated rats compared to ovariectomized, and estrogenprimed rats. LSE administration significantly increased average FSH secretion in ovariectomized, estrogen-primed rats but had no effect in the ovariectomized, estrogen-primed, and progesterone-treated rats. Administration of GnRH at $10 \mathrm{ng} / \mathrm{mL}$ had no effect of FSH secretion. Future studies should investigate the use of a higher concentration of GnRH to stimulate the surge of FSH. There may be differential regulation of FSH secretion due to the increased average FSH secretion observed in the ovariectomized, estrogen-primed, and LS aqueous extract treated rats [56].

\section{ANTI-INFLAMMATORY AND ANTIARTHRITIC ACTIVITY}

For this study, the protein denaturation bioassay was selected for in vitro assessment of the anti-inflammatory property of the methanol extract of L. sativum seeds. Denaturation of tissue proteins is one of the well-documented causes of inflammatory and arthritis diseases. Production of autoantigens in certain arthritic disease conditions may be due to denaturation of tissue proteins in vivo. L. sativum act as anti inflammatory agent that can prevent protein denaturation. Therefore, it would be worthwhile for anti-inflammatory drug development [57].

\section{CONCLUSION}

Evidenced-based studies on the efficacy and safety of traditional Indian systems of medicine are limited. A critical analysis of literature screened for this review reveals the fact that although the number of diseases for which L. sativum finds use as a medicine is fairly large, its curative efficacy has been assessed only in few cases. In view of the wide range of medicinal uses of L. sativum as mentioned in Ayurveda, Homeopathy, Unani system, and otherwise, it is imperative that more clinical and pharmacological trials should be conducted to investigate the unexploited potential of L. sativum as a drug. L. sativum is a source of medicinally active compounds and has a variety of pharmacological effects. These studies will be helpful to create focus toward L. sativum and may be useful in developing new formulations with more therapeutic and to provide a direction for advance research.

\section{REFERENCES}

1. Darshan S, Ved DK. A balanced perspective for management of Indian medicinal plants. Indian For 2003;129:275-88.

2. Dahanukar SA, Kulkarni RA, Rege NN. Pharmacology of medicinal plants and natural products. Indian J Pharmacol 2000;32:81-118.

3. Scartezzini P, Speroni E. Review on some plants of Indian traditional medicine with antioxidant activity. J Ethnopharmacol 2000;71:23-43.
4. Maghrani M, Zeggwagh NA, Michel JB, Eddouks M. Antihypertensive effect of Lepidium sativum L. In spontaneously hypertensive rats. J Ethnopharmacol 2005;100:193-7.

5. Wright CI, Van-Buren L, Kroner CI, Koning MM. Herbal medicines as diuretics: A review of the scientific evidence. J Ethnopharmacol 2007; 114:1-31

6. Al-Yahya MA, Mossa JS, Ageel AM, Rafatullah S. Pharmacological and safety evaluation studies on Lepidium sativum L. seeds. Phytomedicine 1994;1:155-9.

7. Jabeen A, Rani S, Ibrahim M, Mohammad AS. A review on Lepidium sativum. Indo Am J Pharm Sci 2017;4:2223-7.

8. Nadkarni AK. Indian Meteria Medica, with Ayurvedic, Unani-Tibbi, Siddha, Allopathic, Homeopathic, Naturopathic and Home Remedies, Appendices and Indexes. $3^{\text {rd }}$ ed. Panvel: Dhootapeshwar Prakashan Ltd.; 1954. p. 736-7.

9. Tuncay O, Esiyok D, Yagmur B, Bulent OB. Yield and quality of garden cress affected by different nitrogen sources and growing period. Afr J Agric Res 2011;6:608-17.

10. Theodore C. The Flora of the Precidency of Bombay. Vol. 3. Calcutta: Botanical Survey of India; 1967.

11. Guha M, Doke S. Garden cress (Lepidium sativum L.) seed an important medicinal source: A review. J Nat Product Plant Resour 2014;4:69-80.

12. Raval ND, Pandya TN. Pharmacognostic study of Lepidium sativum Linn (Chandrashura). Int Q J Res Ayurveda 2011;32:116-9.

13. Sharma PC, Yelne MB, Dennis T. Database on Medicinal Plants Used in Ayurveda. India: Central Council for Research in Ayurveda and Siddha; 2000. p. 65-72.

14. Ahmed R, Mujeeb M, Anwar F, Hussain A, Ahmed A, Sharma S. Pharmacognostical and phytochemical analysis of Lepidium sativum L. Seeds. Int Curr Pharm J 2015;4:442-6.

15. Cartea ME, Francisco M, Soengas P, Velasco P. Phenolic compounds in brassica vegetables. Molecules 2010;16:251-80.

16. Xiao J, Muzashvili TS, Georgiev MI. Advances in the biotechnological glycosylation of valuable flavonoids. Biotechnol Adv 2014;32: 1145-56.

17. Hassan LG, Hassan SW, Hasim T, Umar KJ, Sani NA. Determination of nutritive values of Garden cress leaves. Bayero J Pure Appl Sci 2011;4:18-23.

18. Agarwal J, Verma DL. Antioxidant activity-guided fractionation of aqueous extracts from Lepidium sativum and identification of active flavonol glycosides. Acad Arena 2011;3:14-8

19. Divanji M, Viswanatha GL, Nagesh S, Jain V, Shivaprasad HN. Ethnopharmacology of Lepidium sativum Linn (Brassicaceae): A review. Int J Phytother Res 2012;2:1-7.

20. Diwakar BT, Dutta PK, Lokesh BR, Naidu KA. Physicochemical properties garden cress (Lepidium sativum) seed oil. J Am Oil Chem Soc 2010;87:539-48.

21. Datta PK, Diwakar BT, Viswanatha S, Murthy KN, Naidu KA. Safety evaluation studies on garden cress (Lepidium sativum L.) seeds in Wistar rats. Int J Appl Res Natl Prod 2011;4:37-43.

22. Patel R, Kumar S, Jaiswal R, Rai S, Sahu A, Dwivedi S. Quantitative estimation of fixed oil obtained from seeds of Lepidium sativum Linn. Int J Chem Anal Sci 2010;1:6-9.

23. Mirza M, Navaei MN. Essential oil composition of Lepidium sativum L. Iran J Med Aromat Plants 2006;21:481-8.

24. Mennicke WH, Görler K, Krumbiegel G, Lorenz D, Rittmann N. Studies on the metabolism and excretion of benzyl isothiocyanate in man. Xenobiotica 1988;18:441-7.

25. Mahassni SH, Mahdi-Al-Reemi R. Cytotoxic effect of an aqueous extract of Lepidium sativum L. Seeds on human breast cancer cells. Indian J Tradit Knowl 2013;12:605-14.

26. Kassie F, Laky B, Gminski R, Mersch-Sundermann V, Scharf G, Lhoste E, et al. Effects of garden and water cress juices and their constituents, benzyl and phenethyl isothiocyanates, towards benzo(a)pyrene-induced DNA damage: A model study with the single cell gel electrophoresis/Hep G2 assay. Chem Biol Interact 2003; $142: 285-96$

27. Kassie F, Pool-Zobel B, Parzefall W, Knasmüller S. Genotoxic effects of benzyl isothiocyanate, a natural chemopreventive agent. Mutagenesis 1999;14:595-604.

28. Shehzad M, Tanveer A, Ayub M, Mubeen K, Sarwar N, Ibrahim M, et al. Effect of weed-crop competition on growth and yield of garden cress (Lepidium sativum L.). J Med Plants Res 2011;5:6169-72.

29. Maier UH, Gundlach H, Zenk MH. Seven imidazole alkaloids from Lepidium sativum. Phytochemistry 1998;49:1791-5.

30. Czapecka E, Mareczek A, Leja M. Antioxidant activity of fresh and dry herbs of some Lamiaceae species. Food Chem 2005;93:223-6. 
31. Arkroyd WR, Gopalan C, Balasubramanian SC. Nutritive Value of Indian Foods and the Planning of Satisfactory Diets. New Delhi: Indian Council of Medical Research; 1960. p. 64.

32. Mathews S, Singhal RS, Kulkarni PR. Some physicochemical characteristics of Lepidium sativum (haliv) seeds. Nahrung 1993;37:69-71.

33. Gokavi SS, Malleshi NG, Guo M. Chemical composition of garden cress (Lepidium sativum) seeds and its fractions and use of bran as a functional ingredient. Plant Foods Hum Nutr 2004;59:105-11.

34. Divekar VB, Kalaskar MG, Chougule PD, Redasani VK, Baheti DG. Isolation and characterization of mucilage from Lepidium sativum Linn. Seeds. Int J Pharm Res Dev 2010;2:1-5.

35. Nadkarni KM. Indian Materia Medica. Mumbai: Popular Prakashan; 1996. p. 596-9.

36. Kirthikar KR, Basu BD. Indian Medicinal Plants. Dehradun: Popular Publications; 1999. p. 1224-7.

37. Bigoniya P, Singh CS, Shukla A. Pharmacognostical and physicochemical standardization of ethnopharmacologically important seeds of Lepidium sativum Linn. and Wrightia tinctoria R. Br. Indian J Natl Prod Resour 2011;2:464-71.

38. 5. Sciarrillo R, Guarino M, Guarino C. Pharmacological activity of ethanolic extract Lepidium sativum Linn. Seeds on thyroid hormones in male rats. Int J Pharm Sci Res 2018;9:1699-704.

39. Gupta PC, Pant D, Joshi P, Lohar DR. Evaluation of antibacterial activity of Lepidium sativum Linn. Seeds against food-borne pathogens. Int J Chem Anal Sci 2010;1:74-5.

40. George RE, Thomas SK, Kunjumon M, Thankamani V. Analysis of phytoconstituents and in vitro antifungal evaluation of methanolic extract of Lepidium sativum Linn. Seeds. Int J Pharm Bio Sci 2015;6:490-7

41. Malara J, Chairmanb K, Singh AR, Vanmathid JS, Balasubramaniana A, Vasanthie K.Antioxidative activity of different parts of the plant Lepidium sativum Linn. Biotechnol Rep 2014;3:95-8.

42. Ait-Yahia O, Bouzroura SA, Belkebir A, Kaci S, Aouichat AB. Cytotoxic activity of flavonoid extracts from Lepidium sativum (Brassicaceae) seeds and leaves. Int J Pharmacogn Phytochem Res 2015;7:1231-5.

43. Patel U, Kulkarni M, Undale V, Bhosale A. Evaluation of diuretic activity of aqueous and methanol extracts of Lepidium sativum garden cress (Cruciferae) in rats. Trop J Pharm Res 2009;8:215-9.

44. Raish M,AhmadA,Alkharfy KM,Ahamad SR, Mohsin K, Al-Jenoobi FI, et al. Hepatoprotective activity of Lepidium sativum seeds against
D-galactosamine/lipopolysaccharide induced hepatotoxicity in animal model. BMC Complement Altern Med 2016;16:501.

45. Shukla A, Bigoniya P, Shrivastava B. Hypoglycemic activity of Lepidium sativum Linn seed total alkaloid on alloxan induced diabetic rats. Res J Med Plant 2012;6:587-96.

46. Elshal MF, Almalki AL, Hussein HK, Khan JA. Synergistic antiosteoporotic effect of Lepidium sativum and alendronate in glucocorticoid-induced osteoporosis in Wistar rats. Afr J Tradit Complement Altern Med 2013;10:267-73.

47. Rehman NU, Khan AU, Alkharfy KM, Gilani AH. Pharmacological basis for the medicinal use of Lepidium sativum in airways disorders. Evidence Based Complement Altern Med 2012;2012:1-8.

48. Paranjape AN, Mehta AA. A study on clinical efficacy of Lepidium sativum seeds in treatment of bronchial asthma. Iran $\mathrm{J}$ Pharmacol Ther 2006;5:55-9.

49. Atasan SK. Studies on some herbal drugs used in fracture healing. Int J Crude Drug Res 1989;27:235-9.

50. Vohora SB, Khan MS. Pharmacological studies on Lepidium sativum, Linn. Indian J Physiol Pharmacol 1977;21:118-20.

51. Kassie F, Rabot S, Uhl M, Huber W, Qin HM, Helma C, et al. Chemoprotective effects of garden cress (Lepidium sativum) and its constituents towards 2-amino-3-methyl-imidazo[4,5-f]quinoline (IQ)-induced genotoxic effects and colonic preneoplastic lesions. Carcinogenesis 2002;23:1155-61

52. Ziska P, Kind A, Franz H. Isolation and characterization of a lectin from garden cress (Lepidium sativum). Acta Histochem 1982;71:29-33.

53. AlObaidi LA. Study the anticancer effect of Lepidium sativum leaves extract on squamous cell carcinoma (CAL-27) cell lines. J Nat Sci Res 2014;417:48-52.

54. Rehmana N, Mehmooda MH, Alkharfyc KM, Gilani AH. Prokinetic and laxative activities of Lepidium sativum seed extract with species and tissue selective gut stimulatory actions. J Ethnopharmacol 2011; 134:878-83.

55. Kaur T, Sharma M. Garden cress seeds can combat anemia. Int J Nutr Agric Res 2016;3:10-5.

56. Jacob PW. Lepidium sativum Effects on Reproduction and Visceral Organ Development in Sprague-Dawley Rats Culminating Projects in Biology; 2017. p. 25

57. Reddy SK, Rao VV, Fathima B, Kapila M, Srilakshmi M. In-vitro anti inflammatory activity of ultra sonic bath assisted, methanol extract of Lepidium sativum Linn. Seeds. Int J Pharm Dev Technol 2013;3:63-5. 